\title{
Glutathione S-Transferase P1 (GSTP1) gene polymorphism increases age-related susceptibility to hepatocellular carcinoma
}

\author{
Yao-Li Chen ${ }^{1,2}$, Hsin-Shun Tseng ${ }^{1}$, Wu-Hsien Kuo ${ }^{3,4}$, Shun-Fa Yang ${ }^{5}$, Dar-Ren Chen ${ }^{1,2^{*}}$, Hsiu-Ting Tsai ${ }^{6,7^{*}}$
}

\begin{abstract}
Background: Hepatocellular carcinoma (HCC) is one of the most frequent malignant neoplasms in the world. Genetic polymorphism has been reported to be a factor increasing the risk of HCC. Phase II enzymes such as glutathione s-transferases (GSTP1, GSTA1) play important roles in protecting cells against damage induced by carcinogens. The aim of this study was to estimate the relationship of the GSTP1 and GSTA1 gene polymorphisms to HCC risk and clinico-pathological status.

Methods: Polymerase chain reaction-restriction fragment length polymorphism (PCR-RFLP) was used to measure GSTP1 $(A \rightarrow G)$ and GSTA1 $(C \rightarrow$ T) gene polymorphisms in 386 healthy controls and 177 patients with HCC.

Results: Neither gene polymorphism was associated with the clinico-pathological status of HCC and serum expression of liver-related clinico-pathological markers. No association between the GSTA1 gene polymorphism and HCC susceptibility was found. However, in the younger group, aged $\leq 57$ years, individuals with AG or GG alleles of GSTP1 had a 2.18-fold $(95 \% \mathrm{Cl}=1.09-4.36 ; \mathrm{p}=0.02)$ and 5.64 -fold $(95 \% \mathrm{Cl}=1.02-31.18 ; \mathrm{p}=0.04)$ risk, respectively, of developing HCC compared to individuals with AA alleles, after adjusting for other confounders.
\end{abstract}

Conclusion: AG and GG alleles of GSTP1 gene polymorphisms may be considered as factors increasing the susceptibility to and risk of HCC in Taiwanese aged $\leq 57$ years.

\section{Background}

Hepatocellular carcinoma (HCC) is one of the common causes of cancer-related death worldwide [1,2], and is the second leading cause of cancer death in Taiwan [3]. Phase II enzymes such as glutathione s-transferases (GSTP1, GSTA1) have been suggested to play an important role in protecting cells against damage induced by carcinogens, through regulation of the conjugation of a wide range of xenobiotics for excretion of hydrophilic metabolites [4-6]. The isoenzymes of glutathione transferases, GSTP1 [7-10] and GSTA1 [7,8,11,12], were found in several mammalian species $[7,8]$ and nontumorous liver tissues [9-12]. Significantly increased expression of GSTP was demonstrated in early hepatocarcinogenesis [12] and HCC specimens [13], compared to their adjacent normal tissues or liver cirrhosis tissues.

\footnotetext{
* Correspondence: darren_chen@cch.org.tw; tsaihsiuting@yahoo.com.tw ${ }^{1}$ Department of Surgery, Changhua Christian Hospital, Changhua, Taiwan ${ }^{6}$ School of Nursing, Chung Shan Medical University, Taichung, Taiwan
}

Loss of GSTP1 has been suggested to increase the risk of DNA damage and mutation [14,15]. An aberrant hypermethylation of GSTP1 promoter $[9,10,16]$ and a subsequently induced lack of GSTP1 mRNA or protein expression were demonstrated in liver cancer cell lines [16], and in more than $77.8 \%$ of HBV-associated HCC tissues [9], respectively. Moreover, up-expression of GSTA was suggested to protect liver cells against oxidative stress $[17,18]$ via an extracellular signal-regulated kinases (ERKs) and p38 kinase (p38K)-related pathway [18], as well as through the inhibition of $\mathrm{H}_{2} \mathrm{O}_{2}$-induced apoptosis to inhibit reactive oxygen species (ROS)induced lipid peroxidation [17].

It was suggested that inactivated or down-regulated GSTP1 [4,5,9,14,15,19-22] and GSTA1 [23] genes could increase genomic damage when individuals were exposed to carcinogens. The GSTP1 gene, encoding glutathione S-transferase-pi and located on chromosome 11q13, was found with a single nucleotide substitution $(A \rightarrow G)$ at position 313 , which resulted in replacing 
isoleucine (Ile) with valine (Val), substantially reduced GSTP1 enzyme activity [24,25], and induced slightly higher adduct levels in liver tissues [26]. Moreover, a wild genotype $\mathrm{C}$ at -69 in the promoter region of the human GSTA1 gene, designated as GSTA1* A, was substituted for $\mathrm{T}$, designated as GSTA1*B, which resulted in decreasing GSTA1 enzyme expression or activity $[11,27,28]$. We therefore hypothesized that the phase II glutathione S-transferase (GST) genes, GSTP1 and GSTA1, were sensitive marker enzymes for preneoplastic and neoplastic liver cells, and genetic polymorphisms of these two enzymes could facilitate the susceptibility to and clinico-pathological development of HCC among Taiwanese, because more than $67 \%$ of male HCC patient and $55.2 \%$ of female HCC patient in Taiwan is related to hepatitis $B$ virus (HBV) infection and $\mathrm{HCV}$ hepatitis $\mathrm{C}$ virus (HCV) infection, respectively [29], which are considered to be the important risk factors of $\mathrm{HCC}$ [26,30,31]; genetic polymorphisms of GSTP1 and GSTA1 could decrease the function of detoxification $[11,24,25,27,28]$ when individuals are exposed to those risk factors. However, the roles of GSTP1 and GSTA1 gene polymorphisms in the susceptibility to HCC among Taiwanese have not been fully clarified. The purpose of this study was to investigate the influence of single nucleotide polymorphisms (SNPs) of the phase II GSTs, GSTP1 and GSTA1, on the susceptibility to and clinico-pathological development of HCC among Taiwanese.

\section{Methods}

\section{Subjects and specimen collection}

This was a hospital-based case-control study. A total of 177 patients with HCC diagnosed at Chung Shan University Hospital, Taichung, or Changhua Christian Hospital, Changhua, Taiwan, were recruited as a case group between April 2006 and August 2009. The diagnoses of HCC were according to the characteristic criteria of the national guidelines for HCC [32], and included liver injury diagnosed by either histology or cytology irrespective of a-fetoprotein (AFP) titer, in which imaging data showed any one of the following three cases: 1) one or more liver masses more than or equal to $2 \mathrm{~cm}$ in diameter via both computed tomography (CT) and magnetic resonance imaging (MRI); 2) one imaging data with early enhancement and a level of AFP more than or equal to $400 \mathrm{ng} / \mathrm{mL}$; and 3) one imaging data with early arterial phase contrast enhancement plus early venous phase contrast washout regardless of AFP level. A total of 386 healthy controls were selected from those who visited the Department of Family Medicine, Chung Shan Medical University Hospital, Taiwan for health examination, based on not having a risk related to hepatocellular carcinoma and matched on demographic data of race, ethnic group, gender, and residential area. The whole blood specimens collected from the healthy controls and HCC patients were placed in tubes containing EDTA and immediately centrifuged and stored at $-80^{\circ} \mathrm{C}$. Associated clinico-pathological characteristics, such as HBsAg, anti-HCV, liver cirrhosis history, Child-Pugh grade, AFP, aspartate aminotransferase (AST), alanine aminotransferase (ALT), and stage of HCC, were verified by chart review. This study was performed with the approval of the Chung Shan University Hospital Institutional Review Board, and written informed consent was obtained from each individual.

\section{Genomic DNA extraction}

Venous blood obtained from each subject was drawn into Vacutainer tubes containing EDTA and stored at $4^{\circ} \mathrm{C}$. Genomic DNA was extracted using a commercial kit for extracting blood DNA (Qiagen, Valencia, USA), according to the manufacture's instructions. DNA was dissolved in TE buffer [10 mM Tris (PH 7.8), $1 \mathrm{mM}$ EDTA] and then quantitated by a measurement of $\mathrm{OD} 260$. The final preparation was stored at $-20^{\circ} \mathrm{C}$ and used as a template for polymerase chain reaction (PCR).

\section{Polymerase chain reaction-restriction fragment length polymorphism (PCR-RFLP)}

The GSTP1 and GSTA1 gene variations test and the primers were modified [33]. The gene detections were amplified by PCR. Briefly, PCR was performed in a $10 \mu \mathrm{l}$ reaction containing $100 \mathrm{ng}$ DNA template, $1.0 \mu \mathrm{l}$ of $10 \times$ PCR buffer (Invitrogen, Carslbad, CA, USA), $0.25 \mathrm{U}$ of Taq DNA polymerase (Invitrogen, Carslbad, CA, USA), $0.2 \mathrm{mM}$ dNTPs (Promega, Madison, WI, USA), and 200 $\mathrm{nM}$ of each primer (MDBio Inc. Taipei, Taiwan). The PCR cycling started at $94^{\circ} \mathrm{C}$ for 5 min followed by 35 cycles of $94^{\circ} \mathrm{C}$ for $1 \mathrm{~min}, 60^{\circ} \mathrm{C}$ for $1 \mathrm{~min}$ and $72^{\circ} \mathrm{C}$ for $2 \mathrm{~min}$, with a final step at $72^{\circ} \mathrm{C}$ for $20 \mathrm{~min}$ to allow a complete extension of all PCR fragments. PCR products of the GSTP1 gene polymorphism were subjected to enzymatic digestion by incubation with BsmA1 for $4 \mathrm{hr}$ at $37^{\circ} \mathrm{C}$ and then electrophoresis in $2 \%$ agarose gels. Wild type homozygous alleles (I/I) yielded 329- and 104-bp products, the heterozygous alleles (I/V) yielded 329-, 222-, 107- and 104-bp products, while the mutated type homozygous alleles (V/V) yielded a 222-, 107- and 104-bp products. PCR products of the GSTA1 gene polymorphism were subjected to enzymatic digestion by incubation with Hinfl for $4 \mathrm{hr}$ at $37^{\circ} \mathrm{C}$ and then electrophoresis in $2 \%$ agarose gels. Wild type homozygous alleles (A/A) yielded 525- and 254-bp products, the heterozygous alleles (A/B) yielded 525-, 254- and 197-bp products, while the mutated type homozygous alleles (B/B) yielded 525- and 197-bp products. 


\section{Power and sample size calculations}

Based on the hypothesis and our preliminary study, the frequencies of at least one mutated allele of GSTP1 and GSTA1 were $29.5 \%(114 / 386)$ and $21.2 \%(82 / 386)$, respectively. Assuming a $95 \%$ confidence interval, a $\mathrm{p}$ value of 0.05 , a ratio of cases to healthy controls of $1: 2$, and at least $90 \%$ power to detect a 2.0 -fold risk in gene variances of GSTP1 and GSTA1, the sample sizes were 150 and 175 case samples for gene polymorphisms of GSTP1 and GSTA1, respectively.

\section{Statistical analysis}

The distributions of demographic characteristics and genotype frequencies between the cases and controls and the clinico-pathological features in different genotypes were analyzed by Fisher's exact test, since the small sample size was present in some categories of variables. The odds ratios (ORs) with their 95\% confidence intervals (CIs) of the association between genotype frequencies and $\mathrm{HCC}$ were estimated by multiple logistic regression models, after controlling for other covariates, including age, gender and genotypes for each estimated variable. A non-parametric method was used because of the non-normal distribution of some estimated variables. The Mann-Whitney $U$ test was used between two groups, and a Kruskal-Wallis test was used among three groups. Hardy-Weinberg equilibrium was assessed using a goodness-of-fit $\chi^{2}$ test for bi-allelic markers. A $p$ value of less than 0.05 was considered significant. The data were analyzed on SAS statistical software (Version 9.1, 2005; SAS Institute Inc., Cary, NC).

\section{Results}

The frequency distributions of GSTP1 and GSTA1 gene polymorphisms were studied in $177 \mathrm{HCC}$ patients and compared to 386 healthy controls. Both gene frequencies were in Hardy-Weinberg equilibrium (GSTP1: $\mathrm{p}>0.05, \chi^{2}$ value: 0.48 ; GSTA1: $\mathrm{p}>0.05, \chi^{2}$ value: 0.17 , respectively) in our recruited healthy control group.

The demographic characteristics and the two gene polymorphism distributions in the HCC patients and healthy controls are shown in Table 1. Except for age $(p<0.0001)$, there was a non-significant difference in distribution of gender, race, ethnic group, residential area, and genetic polymorphisms between the HCC patients and healthy controls, even when we further classified the individuals with at least one mutated allele as one subgroup and regarded the individuals with homozygous wild type alleles as another subgroup to estimate the adjusted odds ratios (AORs) with their 95\% CIs, or combined different genetic distributions for estimating the interaction effect between the GSTP1 and GSTA1 gene polymorphisms on the susceptibility to HCC (Table 1).
Furthermore, we calculated the AOR and their 95\% CIs based on the classification of different age and gender distributions to evaluate the gender- and age-related genetic polymorphism effect on the susceptibility to HCC. Since the mean $( \pm$ SE) and median age of our 563 recruited subjects was $57.36 \pm 0.62$ and 57.0 years, respectively, we classified the individuals aged $\leq 57$ years as one subgroup and those aged $>57$ years as another subgroup. In the younger group, aged $\leq 57$ years, individuals with AG or GG alleles of GSTP1 had a 2.18-fold risk (95\% CI: 1.09-4.36, $\mathrm{p}=0.02$ ) and 5.64-fold risk (95\% CI: 1.02-31.18, p = 0.04), respectively, of developing HCC compared to individuals with AA alleles, after adjustment for other confounders, but no association was found in the older group, aged $>57$ years (Table 2). No association between the GSTP1 gene polymorphism and HCC susceptibility was found when we further estimated the relationship based on gender grouping. In addition, there was no significant relationship between the GSTA1 gene polymorphism and HCC susceptibility when we estimated it based on different age (Table 2) and gender (Table 3) distributions.

To exclude potential selection biases in estimating the genetic effect on HCC risk, the AOR and 95\% CIs of genotypic frequencies and environmental risk factors, such as alcohol, tobacco consumption, detection of hepatitis B surface antigen (HBsAg) and antibody for $\mathrm{HCV}$ (anti-HCV), and history of liver cirrhosis of HCC patients were estimated. There was a non-significant difference in distribution between those risk factors and genetic distributions in our recruited HCC patients. The AORs with their $95 \%$ CIs of GSTP1 and GSTA1 gene polymorphisms on the clinico-pathological characteristics, such as clinical stage, tumor size, lymph node metastasis, distant metastasis, and Child-Pugh grade in HCC patients were also estimated. We found no association between those estimated clinico-pathological characteristics and gene polymorphisms of GSTP1 and GSTA1. Furthermore, we estimated the relationship between genotypic frequencies and expression levels of clinical pathological markers, such as AFP, AST, and ALT, as well as the ratio of AST to ALT in HCC patients. Similarly, non-significant associations between genetic polymorphisms of GSTP1 and GSTA1 and clinico-pathological markers were found (data not shown).

\section{Discussion}

To the best of our knowledge, this is the first study to provide novel information of GSTP1 and GSTA1 genetic polymorphism effects on HCC risk in Taiwanese.

In this study, based on a $95 \% \mathrm{CI}$ and $\mathrm{p}$ value of 0.05 , the ratio of cases to healthy controls was $1: 2$, our sample size had at least $90 \%$ power to detect a 2.0 -fold risk in 
Table 1 Adjusted odds ratio (AOR) and 95\% confidence intervals (Cls) of hepatocellular carcinoma associated with genotypic frequencies and demographic characteristics distributions.

\begin{tabular}{|c|c|c|c|c|}
\hline Variable & Controls $(n=386)(\%)$ & Patients $(n=177)(\%)$ & OR $(95 \% \mathrm{Cl}) \mathrm{p}$ value & AOR $(95 \% \mathrm{Cl}) \mathrm{p}$ value \\
\hline \multicolumn{5}{|l|}{ GSTP1 } \\
\hline$\|$ & $272(70.5 \%)$ & $112(63.3 \%)$ & 1.00 & 1.00 \\
\hline IV & $107(27.7 \%)$ & $58(32.7 \%)$ & $1.31(0.8-1.9) p=0.16$ & $1.16(0.7-1.7) p=0.46$ \\
\hline W & $7(1.8 \%)$ & $7(4.0 \%)$ & $2.42(0.8-7.0) p=0.10$ & $2.26(0.7-7.1) p=0.16$ \\
\hline$\|$ & $272(70.5 \%)$ & $112(63.3 \%)$ & 1.00 & 1.00 \\
\hline IV or W & $114(29.5 \%)$ & $65(36.7 \%)$ & $1.38(0.9-2.0) p=0.09$ & $1.24(0.8-1.8) p=0.28$ \\
\hline
\end{tabular}

\begin{tabular}{lllll}
\hline GSTA1 & & & \\
\hline $\mathrm{AA}$ & $304(78.8 \%)$ & $146(82.5 \%)$ & 1.00 & 1.00 \\
\hline $\mathrm{AB}$ & $78(20.2 \%)$ & $30(16.9 \%)$ & $0.80(0.5-1.2) \mathrm{p}=0.34$ & $0.89(0.5-1.4) p=0.66$ \\
\hline $\mathrm{BB}$ & $4(1.0 \%)$ & $1(0.6 \%)$ & $0.52(0.05-4.7) \mathrm{p}=0.56$ & $0.34(0.04-3.5) p=0.38$ \\
\hline $\mathrm{AA}$ & $304(78.8 \%)$ & & 1.00 & 1.00 \\
\hline $\mathrm{AB}$ or BB & $82(21.2 \%)$ & $146(82.5 \%)$ & $0.78(0.4-1.2) \mathrm{p}=0.36$ & $0.85(0.5-1.3) p=0.52$ \\
\hline
\end{tabular}

\begin{tabular}{lllll}
\hline GST genes & & & & \\
\hline Combination 1 & $212(54.9 \%)$ & $92(52.0 \%)$ & 1.00 & 1.00 \\
\hline Combination 2 & $152(39.4 \%)$ & $75(42.3 \%)$ & $1.13(0.7-1.6) p=0.51$ & $1.05(0.7-1.5) p=0.77$ \\
\hline Combination 3 & $22(5.7 \%)$ & $10(5.7 \%)$ & $1.04(0.4-2.4) p=0.81$ & $1.08(0.4-2.5) p=0.84$ \\
\hline
\end{tabular}

\begin{tabular}{|c|c|c|c|c|}
\hline \multicolumn{5}{|l|}{ Age (yrs) } \\
\hline & $54.37 \pm 0.77$ & $63.88 \pm 0.81$ & $p<0.0001$ & \\
\hline \multicolumn{5}{|l|}{ Gender } \\
\hline$\overline{\text { Male }}$ & $257(66.6 \%)$ & $128(72.3 \%)$ & 1.00 & 1.00 \\
\hline Female & $129(33.4 \%)$ & $49(27.7 \%)$ & $0.76(0.5-1.1) p=0.17$ & $1.08(0.7-1.6) p=0.72$ \\
\hline Residential area & Mid-Taiwan & Mid-Taiwan & & \\
\hline Race & Asian & Asian & & \\
\hline Ethnicity & Taiwanese & Taiwanese & & \\
\hline
\end{tabular}

The odds ratios (ORs) with their $95 \%$ Cls were estimated by logistic regression models.

The adjusted odds ratios (AORs) with their $95 \%$ Cls were estimated by multiple logistic regression models, after controlling for age, gender and genotypes for each estimated variable.

Mann-Whitney $U$ test or Fisher's exact test was used between healthy controls and HCC patients.

Combination 1: Individuals with lle/lle of GSTP1 and ${ }^{*} A /{ }^{*} A$ of GSTA.

Combination 2: Individuals with either genotype lle/Val or Val/Val of GSTP1 or genotype ${ }^{*} A /{ }^{*} B$ or ${ }^{*} B /{ }^{*} B$ of GSTA1.

Combination 3: Individuals with genotype lle/Val or Val/Val of GSTP1 and genotype ${ }^{*} \mathrm{~A} /{ }^{*} \mathrm{~B}$ or ${ }^{*} \mathrm{~B} /{ }^{*} \mathrm{~B}$ of GSTA1.

the gene polymorphism of GSTP1 and GSTA1. We found that the allelic frequencies of GSTP1 and GSTA1 were not significantly associated with HCC. McGlynn et al. [34] recruited 231 patients with $\mathrm{HCC}$ and 256 healthy controls to examine the association between gene polymorphisms of GSTP1 and GSTA1 and HCC among Chinese who were considered to have been exposed to high levels of aflatoxin B1, a hepatotoxic mycotoxin induced by fungi of the Aspergillus species.
They found no association between these two gene polymorphisms and HCC risk, and suggested a non-genetic basis for aflatoxin B1-related susceptibility to HCC risk. Also, Munaka et al. [35] found a non-association between the GSTP1 polymorphism and HCC risk among Japanese. Ladero et al. [36] collected 184 white Spanish patients diagnosed with HCC and 248 healthy controls to estimate the role of the GSTP1 and GSTA1 gene polymorphism on HCC risk; a non-relation 
Table 2 Adjusted odds ratio (AOR) and 95\% confidence intervals (Cls) of hepatocellular carcinoma associated with genotypic frequencies in different age groups.

\begin{tabular}{|c|c|c|c|c|}
\hline Variable & Controls n (\%) & Patients n (\%) & OR $(95 \% \mathrm{Cl}) \mathrm{p}$ value & AOR $(95 \% \mathrm{Cl}) \mathrm{p}$ value \\
\hline & \multicolumn{4}{|c|}{ Age $>57$ years old } \\
\hline GSTP1 & $n=149$ & $n=129$ & & \\
\hline ॥ & $93(62.4 \%)$ & $85(65.9 \%)$ & 1.00 & 1.00 \\
\hline IV & $52(34.9 \%)$ & $40(31.0 \%)$ & $0.84(0.5-1.3) p=0.50$ & $0.88(0.5-1.4) p=0.63$ \\
\hline W & $4(2.7 \%)$ & $4(3.1 \%)$ & $1.09(0.2-4.5) p=0.90$ & $1.06(0.2-4.6) p=0.93$ \\
\hline GSTA1 & $\mathrm{n}=149$ & $\mathrm{n}=129$ & & \\
\hline AA & $122(81.9 \%)$ & $106(82.2 \%)$ & 1.00 & 1.00 \\
\hline$A B$ & $24(16.1 \%)$ & $22(17.1 \%)$ & $1.05(0.5-1.9) p=0.86$ & $1.05(0.5-2.0) p=0.87$ \\
\hline \multirow[t]{2}{*}{$\mathrm{BB}$} & $3(2.0 \%)$ & $1(0.8 \%)$ & $0.38(0.03-3.7) p=0.40$ & $0.47(0.04-4.68) p=0.52$ \\
\hline & \multicolumn{4}{|c|}{ Age $\leq 57$ years old } \\
\hline GSTP1 & $n=237$ & $\mathrm{n}=48$ & & \\
\hline$\|$ & $179(75.5 \%)$ & $27(56.3 \%)$ & 1.00 & 1.00 \\
\hline IV & $55(23.2 \%)$ & $18(37.5 \%)$ & $2.17(1.1-4.2) p=0.02$ & $2.18(1.1-4.3) p=0.02$ \\
\hline W & $3(1.3 \%)$ & $3(6.2 \%)$ & $6.63(1.2-34.5) p=0.02$ & $5.64(1.1-31.8) p=0.04$ \\
\hline GSTA1 & $n=237$ & $\mathrm{n}=48$ & & \\
\hline $\mathrm{AA}$ & $182(76.8 \%)$ & $40(83.3 \%)$ & 1.00 & 1.00 \\
\hline$A B$ & $54(22.8 \%)$ & $8(16.7 \%)$ & $0.67(0.2-1.5) p=0.34$ & $0.62(0.2-1.4) p=0.28$ \\
\hline BB & $1(0.4 \%)$ & $0(0 \%)$ & $-p=0.99$ & $-p=0.99$ \\
\hline
\end{tabular}

The odds ratios (ORs) with their $95 \%$ Cls were estimated by logistic regression models.

The adjusted odds ratios (AORs) with their $95 \%$ Cls were estimated by multiple logistic regression models, after controlling for gender and genotypes for each estimated variable.

Table 3 Adjusted odds ratio (AOR) and 95\% confidence intervals (Cls) of hepatocellular carcinoma associated with genotypic frequencies in different gender groups.

\begin{tabular}{|c|c|c|c|c|}
\hline Variable & Controls n (\%) & Patients n (\%) & OR $(95 \% \mathrm{Cl}) \mathrm{p}$ value & AOR $(95 \% \mathrm{Cl}) \mathrm{p}$ value \\
\hline \multicolumn{5}{|c|}{ Male } \\
\hline GSTP1 & $n=257$ & $n=128$ & & \\
\hline$\|$ & $179(69.7 \%)$ & $76(59.4 \%)$ & 1.00 & 1.00 \\
\hline IV & $72(28.0 \%)$ & $47(36.7 \%)$ & $1.53(0.9-2.4) p=0.06$ & $1.41(0.8-2.2) p=0.14$ \\
\hline $\mathrm{W}$ & $6(2.3 \%)$ & $5(3.9 \%)$ & $1.96(0.5-6.6) p=0.27$ & $1.95(0.5-6.7) p=0.29$ \\
\hline GSTA1 & $\mathrm{n}=257$ & $\mathrm{n}=128$ & & \\
\hline$\overline{A A}$ & $200(77.8 \%)$ & $107(83.6 \%)$ & 1.00 & 1.00 \\
\hline$\overline{A B}$ & $53(20.6 \%)$ & $20(15.6 \%)$ & $0.70(0.4-1.2) p=0.22$ & $0.76(0.4-1.3) p=0.35$ \\
\hline$\overline{\mathrm{BB}}$ & $4(1.6 \%)$ & $1(0.8 \%)$ & $0.46(0.05-4.2) p=0.49$ & $0.45(0.04-4.2) p=0.49$ \\
\hline \multicolumn{5}{|c|}{ Female } \\
\hline GSTP1 & $\mathrm{n}=129$ & $\mathrm{n}=49$ & & \\
\hline$\|$ & $93(72.1 \%)$ & $36(73.5 \%)$ & 1.00 & 1.00 \\
\hline IV & $35(27.1 \%)$ & $11(22.4 \%)$ & $0.81(0.3-1.7) p=0.60$ & $0.57(0.2-1.5) p=0.28$ \\
\hline $\mathrm{W}$ & $1(0.8 \%)$ & $2(4.1 \%)$ & $5.16(0.4-58.7) p=0.18$ & $3.67(0.1-107.8) p=0.45$ \\
\hline GSTA1 & $n=129$ & $\mathrm{n}=49$ & & \\
\hline AA & $104(80.6 \%)$ & 39 (79.6\%) & 1.00 & 1.00 \\
\hline$\overline{A B}$ & $25(19.4 \%)$ & $10(20.4 \%)$ & $1.06(0.4-2.4) p=0.87$ & $1.70(0.5-5.3) p=0.36$ \\
\hline$\overline{\mathrm{BB}}$ & $0(0 \%)$ & $0(0 \%)$ & - & - \\
\hline
\end{tabular}

The odds ratios (ORs) with their $95 \%$ Cls were estimated by logistic regression models.

The adjusted odds ratios (AORs) with their $95 \% \mathrm{Cls}$ were estimated by multiple logistic regression models, after controlling for age and genotypes for each estimated variable. 
between the genetic polymorphism and HCC was found. Although these three studies estimated the relationship between GSTP1 and GSTA1 gene polymorphisms and HCC risk based on different populations with allelic frequencies and environmental exposure different from our recruited population, their results were in agreement with ours. There are other possible explanations for why an individual is not susceptible to HCC, aside from the single nucleotide polymorphisms of GSTP1 and GSTA1, such as linked genes.

However, in the younger group, age $\leq 57$ years old, individuals with AG or GG alleles of GSTP1 had a 2.18-fold risk (95\% CI: 1.09-4.36, p $=0.02)$ and 5.64fold risk (95\% CI: 1.02-31.18, $\mathrm{p}=0.04$ ) of developing HCC compared to individuals with AA alleles, after adjustment for other confounders, but no association was found in the older group, aged > 57 years. Increased GSTP gene expression was found during early hepatocarcinogenesis by acetylation of histones $\mathrm{H} 3$ and $\mathrm{H} 4$ and interaction with the specific transcription factor in the promoter regions of the GSTP gene [12]. Moreover, a marked expression of GSTP was found in HCC specimens of HCC patients [13]. It was supposed that normal or increased GSTP1 protein levels or activities contributed to defend normal hepatocytes against a variety of potentially promutagenic stresses $[4-6,14,20]$, assist detoxification, and inhibit mutagenesis [4-6,14,20]. In the present study, the age-related effect of GSTP1 AG and GG alleles on HCC susceptibility in the younger group, aged $\leq 57$ years, but not in the older group, aged $>57$ years, may have resulted from: 1) The younger group, aged $\leq 57$ years, was more likely exposed to HCC-related risk factors [26,29-31]. The G allele of GSTP1 induced the replacement of isoleucine (Ile) with valine (Val) and substantially reduced GSTP1 enzyme activity $[24,25]$, increased the risk of DNA mutation $[14,15]$, and resulted in poor elimination of hydrophilic metabolites [4-6], consequently increasing the susceptibility to HCC when individuals are exposed to carcinogens [9]; 2) Aging was an important risk factor for HCC development [38-40]. The aging effect may have contributed to the non-significant effect of the GSTP1 genetic variant on HCC risk in our older group, because aging-related GSTP1 hyper-methylation was found in normal human tissues [38,39]. This induced the lack of GSTP1 expression $[9,16]$ and may have contributed to carcinogenic development $[38,39]$ and abated the genetic polymorphism effect in the older group. Moreover, different mechanisms contributing to carcinogenesis development were demonstrated in different age groups among other diseases [40,41]. Tremblay et al. [41] recruited 42 young patients (age: 21-40 years) with oral squamous cell carcinomas (OSCCs) and 62 older (age: 60-95 years) OSCCs patients to detect
GSTP1 expression in tumor tissues and found a significantly decreased expression of GSTP1 in the tumors of young patients compared to their nondysplastic mucosa, but an increased expression of GSTP1 in tumors of older patients compared with their nondysplastic mucosa [41]. Although those hypotheses need further demonstration in HCC development, we provided a novel finding, that the GSTP1 gene polymorphism increased age-related susceptibility to HCC, particularly for subjects aged $\leq 57$ years.

Increased serum levels of AST and ALT are highly correlated with increased expression of GSTA1 [42-44] and GSTP1 [45]. In this study, we estimated the roles of these two gene polymorphisms on the clinical status, such as clinical stage, tumor size, lymph node metastasis, distant metastasis, Child-Pugh grade, and the serum expression levels of liver-related clinical pathological markers, such as alpha-fetoprotein, AST, and ALT, as well as the ratio of AST to ALT in HCC patients. A lack of association between the gene polymorphism and those estimated factors was found in both GSTP1 and GSTA1 genes. We propose that the age-related GSTP1 gene polymorphism contributes to the susceptibility to HCC, and not through the alteration of the expression of those clinical pathological markers.

One of the limitations of our study is that we did not obtain information on risk factors, such as alcohol, tobacco consumption, and other hepatocarcinogenesisrelated factors [30] in our recruited healthy control group, because it was difficult to request healthy individuals to provide that information or to collect that data during their health examination. This limitation may impede the adjustment of the confounding variables. However, in order to exclude a potential selection bias in estimating the genetic effect on HCC risk, the AOR and 95\% CIs of genotypic frequencies and environmental risk factors, such as alcohol, tobacco consumption, detection of hepatitis B surface antigen ( $\mathrm{HBsAg}$ ) and antibody for HCV (anti-HCV), and the history of liver cirrhosis of HCC patients, were estimated, and there was a non-significant difference in distribution between those risk factors and the genetic distributions in our recruited HCC patients. Moreover, other demographic characteristics such as age, gender, race, and, residential area were adjusted for estimation of gene polymorphism effect on HCC between the healthy controls and HCC patients. We consider that this limitation is unlikely to bound the estimation of genetic effect on HCC risk in this study.

\section{Conclusion}

AG and GG alleles of GSTP1 gene polymorphisms may be considered as factors increasing the susceptibility to the risk of $\mathrm{HCC}$ in Taiwanese subjects ages $\leq 57$ years. 


\section{List of abbreviations}

CIs: confidence intervals; GST: glutathione S-transferases; HCC: hepatocellular carcinoma; OR: odds ratios; PCR-RFLP: Polymerase chain reaction-restriction fragment length polymorphism; SNP: single nucleotide polymorphism.

\begin{abstract}
Acknowledgements
The authors are grateful to all the research staff who participated in the study, in particular, the Department of General and Family Medicine of Chung Shan University Hospital, Taichung, and of Changhua Christian Hospital, Changhua, Taiwan.

This study was supported by a research grant from Changhua Christian Hospital and Chung Shan University, Taichung, Taiwan (097-CCH-CSMU-12) and National Science Council, Taiwan (NSC-98-2314-B-040-014-MY3).
\end{abstract}

\section{Author details}

'Department of Surgery, Changhua Christian Hospital, Changhua, Taiwan. ${ }^{2}$ School of Medicine, Chung Shan Medical University, Taichung, Taiwan. ${ }^{3}$ Department of Medicine, Armed-Force Taichung General Hospital, Taichung, Taiwan. ${ }^{4}$ General Education Center, Central Taiwan University of Science and Technology, Taichung, Taiwan. ${ }^{5}$ Institute of Medicine, Chung Shan Medical University, Taichung, Taiwan. ${ }^{6}$ School of Nursing, Chung Shan Medical University, Taichung, Taiwan. ${ }^{7}$ Department of Nursing, Chung Shan Medical University Hospital, Taichung, Taiwan.

\section{Authors' contributions}

YLC: planned the analysis, collected samples, interpreted the data, and drafted the manuscript. HST: analyzed the data and participated in the interpretation of the data. WHK: assisted in the study design and participated in the interpretation of the data. SFY: collected samples, and designed and participated in the analysis of polymerase chain reactionrestriction fragment length polymorphism for measuring the gene polymorphism. DRC: conceived the overall study, secured funding, and revised the manuscript. HTT: conceived the overall study, secured funding, and offered critical revisions to the manuscript. All authors have read and approved the content of the manuscript.

\section{Competing interests}

The authors declare that they have no competing interests.

Received: 19 May 2009 Accepted: 24 March 2010

Published: 24 March 2010

\section{References}

1. Bosch FX, Ribes J, Cleries R, Diaz M: Epidemiology of hepatocellular carcinoma. Clin Liver Dis 2005, 9(2):191-211, v.

2. Parkin DM, Bray F, Ferlay J, Pisani P: Global cancer statistics, 2002. CA Cancer J Clin 2005, 55(2):74-108.

3. Department of Health, Republic of China: "Health Statistics: II. Vital Statistics.". Department of Health, Taipei 2007.

4. Jakoby WB: The glutathione S-transferases: a group of multifunctional detoxification proteins. Adv Enzymol Relat Areas Mol Biol 1978, 46:383-414.

5. Chasseaud LF: The role of glutathione and glutathione S-transferases in the metabolism of chemical carcinogens and other electrophilic agents. Adv Cancer Res 1979, 29:175-274.

6. Rebbeck TR: Molecular epidemiology of the human glutathione Stransferase genotypes GSTM1 and GSTT1 in cancer susceptibility. Cancer Epidemiol Biomarkers Prev 1997, 6(9):733-743.

7. Mannervik B, Alin P, Guthenberg C, Jensson H, Tahir MK, Warholm M, Jornvall $\mathrm{H}$ : Identification of three classes of cytosolic glutathione transferase common to several mammalian species: correlation between structural data and enzymatic properties. Proc Natl Acad Sci USA 1985, 82(21):7202-7206.

8. Strange RC, Spiteri MA, Ramachandran S, Fryer AA: Glutathione-Stransferase family of enzymes. Mutat Res 2001, 482(1-2):21-26.
9. Zhong S, Tang MW, Yeo W, Liu C, Lo YM, Johnson PJ: Silencing of GSTP1 gene by $\mathrm{CpG}$ island DNA hypermethylation in HBV-associated hepatocellular carcinomas. Clin Cancer Res 2002, 8(4):1087-1092.

10. Su PF, Lee TC, Lin PJ, Lee PH, Jeng YM, Chen CH, Liang JD, Chiou LL, Huang GT, Lee HS: Differential DNA methylation associated with hepatitis B virus infection in hepatocellular carcinoma. Int J Cancer 2007, 121(6):1257-1264.

11. Coles BF, Morel F, Rauch C, Huber WW, Yang M, Teitel CH, Green B, Lang NP, Kadlubar FF: Effect of polymorphism in the human glutathione S-transferase A1 promoter on hepatic GSTA1 and GSTA2 expression. Pharmacogenetics 2001, 11(8):663-669.

12. Sakai M, Muramatsu M: Regulation of glutathione transferase P: a tumor marker of hepatocarcinogenesis. Biochem Biophys Res Commun 2007 357(3):575-578.

13. Niu ZS, Wang M: Expression of c-erbB-2 and glutathione S-transferase-pi in hepatocellular carcinoma and its adjacent tissue. World J Gastroenterol 2005, 11(28):4404-4408.

14. Lee WH, Morton RA, Epstein Jl, Brooks JD, Campbell PA, Bova GS, Hsieh WS, Isaacs WB, Nelson WG: Cytidine methylation of regulatory sequences near the pi-class glutathione S-transferase gene accompanies human prostatic carcinogenesis. Proc Natl Acad Sci USA 1994, 91(24):11733-11737.

15. Zhang YJ, Chen Y, Ahsan H, Lunn RM, Chen SY, Lee PH, Chen CJ, Santella RM: Silencing of glutathione S-transferase P1 by promoter hypermethylation and its relationship to environmental chemical carcinogens in hepatocellular carcinoma. Cancer Lett 2005, 221(2):135-143.

16. Ding S, Gong BD, Yu J, Gu J, Zhang HY, Shang ZB, Fei Q, Wang P, Zhu JD: Methylation profile of the promoter CpG islands of 14 "drug-resistance" genes in hepatocellular carcinoma. World J Gastroenterol 2004, 10(23):3433-3440.

17. Yang Y, Cheng JZ, Singhal SS, Saini M, Pandya U, Awasthi S, Awasthi YC Role of glutathione S-transferases in protection against lipid peroxidation. Overexpression of hGSTA2-2 in K562 cells protects against hydrogen peroxide-induced apoptosis and inhibits JNK and caspase 3 activation. J Biol Chem 2001, 276(22):19220-19230.

18. Zhang D, Lu H, Li J, Shi X, Huang C: Essential roles of ERKs and p38K in up-regulation of GST A1 expression by Maotai content in human hepatoma cell line Hep3B. Mol Cell Biochem 2006, 293(1-2):161-171.

19. Groopman JD, Cain LG, Kensler TW: Aflatoxin exposure in human populations: measurements and relationship to cancer. Crit Rev Toxicol 1988, 19(2):113-145.

20. Coles B, Ketterer B: The role of glutathione and glutathione transferases in chemical carcinogenesis. Crit Rev Biochem Mol Biol 1990, 25(1):47-70

21. Daniel V: Glutathione S-transferases: gene structure and regulation of expression. Crit Rev Biochem Mol Biol 1993, 28(3):173-207.

22. Qian GS, Ross RK, Yu MC, Yuan JM, Gao YT, Henderson BE, Wogan GN, Groopman JD: A follow-up study of urinary markers of aflatoxin exposure and liver cancer risk in Shanghai, People's Republic of China. Cancer Epidemiol Biomarkers Prev 1994, 3(1):3-10.

23. Li Y, Wan D, Wei W, Su J, Cao J, Qiu X, Ou C, Ban K, Yang C, Yue H: Candidate genes responsible for human hepatocellular carcinoma identified from differentially expressed genes in hepatocarcinogenesis of the tree shrew (Tupaia belangeri chinesis). Hepatol Res 2008, 38(1):85-95.

24. Ali-Osman F, Akande O, Antoun G, Mao JX, Buolamwini J: Molecular cloning, characterization, and expression in Escherichia coli of full-length CDNAs of three human glutathione S-transferase Pi gene variants. Evidence for differential catalytic activity of the encoded proteins. J Biol Chem 1997, 272(15):10004-10012.

25. Jahnke V, Matthias C, Bockmuhl U, Strange RC: [Genetic predisposition for the development of head and neck carcinomas]. Laryngorhinootologie 1999, 78(1):24-27.

26. Chen SY, Wang LY, Lunn RM, Tsai WY, Lee PH, Lee CS, Ahsan H, Zhang YJ, Chen CJ, Santella RM: Polycyclic aromatic hydrocarbon-DNA adducts in liver tissues of hepatocellular carcinoma patients and controls. Int $J$ Cancer 2002, 99(1):14-21.

27. Coles B, Nowell SA, MacLeod SL, Sweeney C, Lang NP, Kadlubar FF: The role of human glutathione S-transferases (hGSTs) in the detoxification of the food-derived carcinogen metabolite $\mathrm{N}$-acetoxy-PhIP, and the effect of a polymorphism in hGSTA1 on colorectal cancer risk. Mutat Res 2001 482(1-2):3-10. 
28. Ping J, Wang H, Huang M, Liu ZS: Genetic analysis of glutathione Stransferase A1 polymorphism in the Chinese population and the influence of genotype on enzymatic properties. Toxicol Sci 2006, 89(2):438-443.

29. Lu SN, Su WW, Yang SS, Chang TT, Cheng KS, Wu JC, Lin HH, Wu SS, Lee CM, Changchien CS, et al: Secular trends and geographic variations of hepatitis B virus and hepatitis C virus-associated hepatocellular carcinoma in Taiwan. Int J Cancer 2006, 119(8):1946-1952.

30. Chen CJ, Yu MW, Liaw YF: Epidemiological characteristics and risk factors of hepatocellular carcinoma. J Gastroenterol Hepatol 1997, 12(9-10): S294-308.

31. Kao JH: Hepatitis B virus genotypes and hepatocellular carcinoma in Taiwan. Intervirology 2003, 46(6):400-407.

32. Centers for Disease Control, Taiwan 2007 [http://www.cdc.gov.tw].

33. Chang TW, Wang SM, Guo YL, Tsai PC, Huang CJ, Huang W: Glutathione Stransferase polymorphisms associated with risk of breast cancer in southern Taiwan. Breast 2006, 15(6):754-761.

34. McGlynn KA, Hunter K, LeVoyer T, Roush J, Wise P, Michielli RA, Shen FM, Evans AA, London WT, Buetow KH: Susceptibility to aflatoxin B1-related primary hepatocellular carcinoma in mice and humans. Cancer Res 2003, 63(15):4594-4601.

35. Munaka M, Kohshi K, Kawamoto T, Takasawa S, Nagata N, Itoh H, Oda S, Katoh T: Genetic polymorphisms of tobacco- and alcohol-related metabolizing enzymes and the risk of hepatocellular carcinoma. J Cancer Res Clin Oncol 2003, 129(6):355-360.

36. Ladero JM, Martinez C, Fernandez JM, Martin F, Garcia-Martin E, Ropero P, Villegas A, Diaz-Rubio M, Agundez JA: Glutathione S-transferases pi 1, alpha 1 and M3 genetic polymorphisms and the risk of hepatocellular carcinoma in humans. Pharmacogenomics 2007, 8(8):895-899.

37. Bartsch H, Rojas M, Nair U, Nair J, Alexandrov K: Genetic cancer susceptibility and DNA adducts: studies in smokers, tobacco chewers, and coke oven workers. Cancer Detect Prev 1999, 23(6):445-453.

38. Kwabi-Addo B, Chung W, Shen L, Ittmann M, Wheeler T, Jelinek J, Issa JP: Age-related DNA methylation changes in normal human prostate tissues. Clin Cancer Res 2007, 13(13):3796-3802.

39. Nishida N, Nagasaka T, Nishimura T, Ikai I, Boland CR, Goel A: Aberrant methylation of multiple tumor suppressor genes in aging liver, chronic hepatitis, and hepatocellular carcinoma. Hepatology 2008, 47(3):908-918.

40. Miki D, Aikata H, Uka K, Saneto H, Kawaoka T, Azakami T, Takaki S, Jeong SC, Imamura M, Kawakami Y, et al: Clinicopathological features of elderly patients with hepatitis $C$ virus-related hepatocellular carcinoma. $J$ Gastroenterol 2008, 43(7):550-557.

41. Tremblay S, Pintor Dos Reis P, Bradley G, Galloni NN, Perez-Ordonez B, Freeman J, Brown D, Gilbert R, Gullane P, Irish J, et al: Young patients with oral squamous cell carcinoma: study of the involvement of GSTP1 and deregulation of the Fanconi anemia genes. Arch Otolaryngol Head Neck Surg 2006, 132(9):958-966.

42. Mulder TP, Janssens AR, de Bruin WC, Peters WH, Cooreman MP, Jansen JB: Plasma glutathione S-transferase alpha 1-1 levels in patients with chronic liver disorders. Clin Chim Acta 1997, 258(1):69-77.

43. Knapen MF, Wildt van der B, Sijtsma EG, Peters WH, Roelofs HM, Steegers EA: Glutathione S-transferase Alpha 1-1 and aminotransferases in umbilical cord blood. Early Hum Dev 1999, 54(2):129-135.

44. van Runnard Heimel PJ, Kavelaars A, Heijnen CJ, Peters WH, Huisjes AJ, Franx A, Bruinse HW: HELLP syndrome is associated with an increased inflammatory response, which may be inhibited by administration of prednisolone. Hypertens Pregnancy 2008, 27(3):253-265.

45. Mannaa F, Ahmed HH, Estefan SF, Sharaf HA, Eskander EF: Saccharomyces cerevisiae intervention for relieving flutamide-induced hepatotoxicity in male rats. Pharmazie 2005, 60(9):689-695.

\section{Pre-publication history}

The pre-publication history for this paper can be accessed here: http://www. biomedcentral.com/1471-2350/11/46/prepub

\section{doi:10.1186/1471-2350-11-46}

Cite this article as: Chen et al:: Glutathione S-Transferase P1 (GSTP1)

gene polymorphism increases age-related susceptibility to

hepatocellular carcinoma. BMC Medical Genetics 2010 11:46.

\section{Submit your next manuscript to BioMed Central and take full advantage of:}

- Convenient online submission

- Thorough peer review

- No space constraints or color figure charges

- Immediate publication on acceptance

- Inclusion in PubMed, CAS, Scopus and Google Scholar

- Research which is freely available for redistribution

Submit your manuscript at www.biomedcentral.com/submit
Biomed Central 